\title{
Version Number Text
}

National Cancer Institute

\section{Source}

National Cancer Institute. Version Number Text. NCI Thesaurus. Code C93703.

A numeric character string that identifies a form or variant of a type or original. 